\title{
Los k'ajchas* y los proyectos de industria y nación en Bolivia (1935-1940)
}

\section{Rossana Barragán Romano**}

Resumen: La Convención de 1938, realizada en la administración presidencial de los "Socialistas Militares", fue expresión de la crisis política que desencadenó la Guerra del Chaco (1932-1935) anunciando las medidas que marcarían gran parte del siglo XX (el mayor rol del estado en la economía, la distribución de la tierra, las políticas hacia los recursos naturales, la ciudadanía de indígenas y de mujeres). Uno de los puntos considerados es si se arrendaban las minas abandonadas del cerro de Potosí a los Ilamados k’ajchas ¿Quiénes eran? ¿Eran pequeños propietarios y patrones? ¿Eran obreros proletarios o eran primitivos mineros? ¿Había que favorecerlos cuando tenían sistemas obsoletos y atrasados de explotación o había que crear sistemas industriales en "manos de la nación"? El trabajo reconstruye, en base a los periódicos de la época y a los redactores de la Convención, la situación de los k'ajchas en el período de crisis económica del estaño y de crisis política del país, analizando también las diversas interpretaciones y los diferentes proyectos que se plantearon en torno a la existencia de grandes empresarios como Mauricio Hothshild, en torno a los proletarios, y en torno a los pequeños mineros. Uno de los argumentos fundamentales que se plantea, es que la industrialización no fue posible pensarse en el contexto de la Convención a partir de los pequeños trabajadores, sino más bien, a través de la construcción de una industria en poder del Estado con sus propios obreros.

Palabras clave: Minería; k’ajchas; pequeña minería; cooperativas mineras; Potosí; historia del trabajo.

\footnotetext{
Abstract: The 1938 Convention took place under the presidential administration of "Military Socialists", as a result of the political crisis generated by the Chaco War (1932-1935), proclaiming political measures that would be implemented during the rest of the twentieth century (an increased role of the state in the economy, land distribution, public policies on natural resources, and indigenous and women citizenships). One of the topics considered was weather to rent Potosi's abandoned mines to the so called K'ajchas. Who were they? Were they small bosses

* En los documentos aparecen como cacchas, capchas o ckachas. El nombre, en quechua, aludía al sonido de la honda utilizada para ahuyentar a las personas que se acercaban a ellos al interior de las minas. Cf. Anónimo, Descripción histórica de Potosí, 1759: 256. Documento proveniente de la British Library cuya copia se encuentra hoy en el Archivo y Biblioteca Nacionales de Bolivia.

** Doctora por la École des Hautes Études en Sciences Sociales de Paris. Instituto Internacional de Historia Social y Coordinadora de Historia.
} 
and mine owners? Were they proletarian workers or primitive miners? Would they have to be favored even though they possessed obsolete and backward system of exploitation or create an industrial system under state control? The study reconstructs, based on newspapers of that period and on Reports of the Convention, the situation of the K'ajchas in a context of the tin economic crisis and the country`s political upheaval. Also is analyzed the different interpretations and projects that were debated around topics such as the presence of large mining enterprises like Mauricio Hothchilds's mines, mining proletarians or small scale mining owners. One of the central arguments discussed was weather the industrialization development plan that emerged from the Convention should consider small miners enterprises or state controlled workers.

Keywords: Mining; K’ajchas; Small-scale mining; Mining cooperatives; Potosí; Labour History.

En el escenario laboral minero boliviano existen actualmente alrededor de 18.000 asalariados y 120.000 Cooperativistas ${ }^{1}$ que han adquirido un poder político impresionante apoyando, pero también desafiando al Movimiento al Socialismo (MAS) y al Presidente Evo Morales. ${ }^{2}$ Aunque la "explosión" en su número se dio en los últimos 35 años, fueron los antiguos k'ajchas, trabajadores a destajo para entonces, los que se convirtieron en cooperativistas mineros a partir de la década de 1940 consolidándose después de la Revolución de 1952.3 Ellos nos obligan a pensar que los obreros asalariados son y han sido, en países como Bolivia, un grupo importante pero restringido, y hasta privilegiado. La mayoría de hombres y mujeres tuvieron que crear, como hoy en día, sus propias fuentes de ingreso (como los llamados actualmente "cuenta propia"). Por las características de sus actividades quedan sin embargo pocas huellas a través del tiempo.

A pesar de la trascendencia de k'ajchas y cooperativistas, no tenemos hasta hoy un libro sobre su propia historia, aunque varios autores importantes se han referido a ellos, desde 1959. Los k'ajchas irrumpieron en el escenario minero en el siglo XVIII para no desaparecer y abrieron la discusión política nacional en el siglo XX sobre las posibilidades de una economía minera que no se basara exclusivamente en los grandes y medianos empresarios.

En la investigación que realizamos sobre los k’ajchas en la segunda mitad del siglo XVIII,4 ellos fueron descritos, por las autoridades y empresarios, como

1 Datos que se encuentran en: “Mineros asalariados cuestionan los privilegios de los cooperativistas, afines a Evo". http://eju.tv/2013/06/mineros-asalariados-cuestionan-los-privilegios-de-los-cooperativistas-afinesa-evo/. Consultado el 31 de Enero del 2017.

2 La cooperativa es definida hoy como una "asociación sin fines de lucro, de personas naturales y/o jurídicas que se asocian voluntariamente... para satisfacer sus necesidades productivas y de servicios, con estructura y funcionamiento autónomo y democrático". Se menciona en la ley principios como la equidad, la solidaridad y el no lucro de sus asociados. Exclusión de actividades con fines especulativos, de forma que no se acumulen las ganancias para enriquecer a las asociadas o los asociados". No se define lucro, pero parece descartarse todo beneficio económico. Cf. Ley No. 356, 11 de abril de 2013 bajo la presidencia de Evo Morales. La idea del no lucro va actualmente más allá de la formulación que existía a fines de los 50. Ver nota siguiente.

3 En 1958, el Presidente Hernán Siles Suazo dio el Decreto Ley de las Sociedades Cooperativas $\mathrm{N}^{\circ}$ 5035, del 13 de septiembre de 1958. Decía: "Que esas asociaciones cooperativas surgidas espontáneamente, como obra de la iniciativa popular, en los campos, las minas, las fábricas y los talleres, exigen una pronta canalización económica y jurídica" y que "El objetivo de la sociedad no es el lucro sino la acción conjunta de los socios para su mejoramiento económico y social y para extender los beneficios de la educación cooperativa y la asistencia social a toda la comunidad".

4 Estos k’ajchas fueron importantes a partir del siglo XVIII. Cf. BARRAGÁN, Rossana. “¿Ladrones, pequeños 
ladrones de mineral. Nosotros enfatizamos el cuestionamiento que implicaba su sola existencia para el sistema de propiedad de las minas en Potosí, y a la estrecha articulación que tuvieron con los trapiches o molinos rudimentarios, lo que implica que no solo extraían los minerales del cerro sin tener concesiones (lo que suscita el tema de la propiedad), sino que además los procesaban para obtener plata que la vendían al propio Banco de San Carlos. Subrayamos también, la existencia de mujeres como propietarias de trapiches y como vendedoras de plata. A principios del siglo XIX (a partir de la fundación de la república), los k’ajchas reinaban en el cerro produciendo el $50 \%$ de la plata, disminuyendo este valor a solo el $20 \%$ entre 1831 y 1850.5 Por entonces, encontramos compartían la producción con los propietarios de las minas con quienes tenían un acuerdo de convivencia. ${ }^{6}$ Podían ser particularmente importantes en períodos de auge porque podían obtener muy fácil y rápidamente minerales muy ricos, pero eran también requeridos por los propios empresarios, en períodos de declive de la producción, cuando los propietarios preferían trabajar erogando menos gastos y costos.

A partir de este rapidísimo recuento, es posible interpretar su relación con los empresarios de dos maneras que no son excluyentes: por un lado, que se fueron imponiendo logrando que las autoridades los reconozcan y que los dueños negocien con ellos, obteniendo, sin ser propietarios concesionarios, una parte de la producción. Pero también, que fueron perdiendo fuerza y la independencia que tenían en el siglo XVIII, convirtiéndose en obreros a destajo, una modalidad conveniente también para los empresarios.

En este artículo nos interesa analizar otro momento fundamental en la historia de los k'ajchas: el período entre 1938-1940, en el contexto de la post-guerra del Chaco, que abrió una nueva época en Bolivia marcada, esta vez, por la producción de estaño. Pascale Absi ha planteado el proceso que habría ido de "contratistas a partición" de los k'ajchas a cooperativistas organizados.? La pregunta que surge es clara ¿Cómo fue posible que estos trabajadores lograran recibir la autorización de trabajar las minas y explotarlas como los empresarios? ¿Cómo entender que dejaran de ser obreros a destajo para convertirse en arrendatarios? ¿Cómo entender que en lugar de que se buscara su incorporación y sumisión a las empresas existentes implicando su proletarización y su disciplinamiento, fueran reconocidos por el Estado para convertirse en cooperativistas?

Planteo que tres factores ayudan a explicar su conversión a arrendatarios y concesionarios del Estado. En primer lugar, junto a la continuidad de su existencia en el siglo XIX y XX, es fundamental considerar la situación de la minería en el país en la post-guerra del Chaco y, de manera aún más específica, la producción y comercialización del estaño en el cerro Rico de Potosí, temas que analizamos

empresarios o trabajadores independientes? K’ajchas, trapiches y plata en el cerro de Potosí en el siglo XVIII". Nuevo Mundo Mundos Nuevos, 2015, que es una versión corta de un trabajo más largo “K’ajchas, trapiches y plata en el cero de Potosí en el período colonial”. Anuario. Estudios Bolivianos, Archivísticos y Bibliográficos. 20, 2014, 273-320. Un artículo que abarca el conjunto del período colonial y la problemática laboral se encuentra en "Working Silver for the World: Mining Labor and Popular Economy in Colonial Potosi”. Hispanic American Historical Review, 97, May 2017, 193-222.

5 ABSI, Pascale. Los ministros del Diablo. El trabajo y sus representaciones en las minas de Potosí. La Paz: IRD, Instituto de Investigación para el Desarrollo; Embajada de Francia en Bolivia; IFEA, Instituto Francés de Estudios Andinos; Fundación PIEB, 2005, p. 20.

6 PLATT, Tristan. "Producción, tecnología y trabajo en la Rivera de Potosí durante la República temprana". In: BARRAGÁN, Rossana, QAYUM, Seemin y SOUX, María Luisa (Org.). El siglo XIX: Bolivia y América Latina. Travaux de l'IFEA 102: La Paz, 1997.

7 ABSI, Pascale. "Q'aqchas y obreros: apuntes sobre la organización del trabajo minero". Anuario Estudios Bolivianos Archivísticos y Bibliográficos, 2014, p. 240. 
en la primera parte de este trabajo. En segundo lugar, se debe tomar en cuenta la discusión y apertura política que significó la realización de la Convención o Asamblea Constituyente de 1938. Se inició así lo que Klein consideró para Bolivia como el constitucionalismo social (recuperando en realidad el análisis de los juristas latinoamericanos y del abogado boliviano Oscar Frerking), y que Drinot considera el Estado del Trabajo para el Perú. ${ }^{8}$ Pero, ¿qué términos utilizaron los actores políticos de entonces y quiénes eran? Se trata, en realidad, de una diversidad de intelectuales y grupos obreros aglutinados en múltiples organizaciones que tenían diferentes perspectivas, pero que confluyeron en su crítica al liberalismo individualista, a los derechos políticos abstractos y al poder económico de los grandes empresarios, encarnados en Bolivia en los barones de la minería. Ellos buscaron lo que consideraron justicia social y un Estado social que suponía un Estado regulador e intervencionista con poder económico al servicio de la sociedad. Buscaron por tanto "devolver a Bolivia su soberanía económica”. ${ }^{9}$ Era lo que ellos consideraron el Estado Socialista. ${ }^{10}$ En tercer lugar, y en este contexto, se fueron pensando en políticas estatales que se discutieron y dieron a favor de los k'ajchas en el cerro de Potosí, tema que abordamos en una tercera parte. Concluimos refiriéndonos a las ambigüedades y limitaciones que tuvo ese reconocimiento.

\section{La época y la situación de la minería}

La guerra del Chaco, entre 1932 y 1935, movilizó a más de 250.000 personas en un país de alrededor de dos millones y medio, supuso la pérdida de más de 65.000 personas y la amputación de un inmenso y rico territorio. No es extraño, por tanto, que fuese un período de crisis y reflexión que demarcaría un antes y un después en la historia boliviana. Una de sus inmediatas expresiones fue la toma del poder por una coalición de Militares autodenominados Socialistas, encabezados por David Toro (1936-1937) y Germán Busch (1937-1939), los civiles socialistas liderados por Baldivieso y los Republicanos Socialistas de Saavedra. David Toro explicó que buscaba instaurar un socialismo de Estado con la ayuda de los partidos de izquierda. ${ }^{11}$ Su movimiento político era en defensa de las clases trabajadoras y de los Excombatientes. En este contexto, y por demanda de las organizaciones de los trabajadores, se creó el Ministerio de Trabajo nombrándose como Ministro al obrero Waldo Alvarez, linotipista de la Federación Obrera del Trabajo (FOT) que se rodeó de intelectuales marxistas y dirigentes obreros, ${ }^{12}$ suscitando oposición de

8 Klein citó el libro Las claúsulas económico-sociales en las constituciones de América, 2 vols. Buenos Aires. 1947-1948 y el artículo en ese libro de Oscar Frerking, "Las claúsulas económicos sociales en la Constitución política de Bolivia”. DRINOT, Paulo. La seducción de la clase obrera. Trabajadores, raza y la formación del Estado peruano. Lima: Instituto de Estudios Peruanos y Ministerio de Cultura, 2016.

9 KLEIN, Herbert. Orígenes de la revolución nacional boliviana: La crisis de la generación del Chaco. La Paz: Librería Juventud, 1968, p. 268.

10 En la nueva constitución aprobada, el nuevo acápite sobre el Régimen Económico Financiero estableció que éste "debía responder a los principios de justicia social que tienen como objetivo asegurar para todos... una existencia digna..." y que para ello el Estado podía regular la industria o asumir "la dirección suprema" sobre la economía social.

11 KLEIN. Orígenes de la revolución nacional boliviana, p. 263 y SCHELCHKOV, Andrey. "Antes de la Convención: la búsqueda de un nuevo modelo estatal - el experimento militar-socialista". Inédito.

12 KLEIN. Orígenes de la revolución nacional boliviana, p. 271 y p. 288. En el Ministerio de Trabajo estuvo, durante un tiempo, José Aguirre Gainsborg, un conocido marxista, fundador del POR (Partido Obrero Revolucionario). El segundo hombre fuerte en este Ministerio fue el marxista José Antonio Arze, además de Ricardo Anaya. SCHELCHKOV. “Antes de la Convención”, p. 16-17. El Ministro Waldo Alvarez, cuando se trabajaban con las organizaciones sindicales (Asambleas Nacionales Permanentes de las Organizaciones Sindicales, ANPOS), pidió que se tuvieran reuniones con los Sindicatos en el hemiciclo del Senado, p. 26. 
los grupos tradicionales. Se tomaron, entonces, varias medidas como reunir a las organizaciones sindicales incluyendo a representantes de todas las Federaciones Locales y de Trabajadores, elaborándose también leyes de seguridad social y un nuevo Código del Trabajo. Aunque se criticó el decreto de sindicalización obligatoria como una influencia nazista, la medida fue un contrapoder a los partidos políticos tradicionales desatando una ola organizativa que sin duda está aún por estudiarse. ${ }^{13}$

Resulta significativo que a los pocos meses del gobierno de Toro se realizó, en noviembre de 1936, el Congreso Obrero Nacional en Oruro que convocó a más de 213 organizaciones sindicales que se decía representaban alrededor de 70.000 obreros. ${ }^{14} \mathrm{El}$ resultado fue la creación de la Confederación Sindical de los Trabajadores de Bolivia (CSTB) que redactó un pliego de peticiones solicitando el traspaso al Estado del 40\% de las utilidades de laminería, la eliminación de las concesiones a la Standard Oil, el control del Estado sobre los flujos monetarios y de oro, la industrialización forzosa, la reforma constitucional y el derecho de los sindicatos a participar en las elecciones. El Estado buscó también, tener a los grupos obreros bajo su tutela, fundando, el 7 de abril de 1937, el Partido del Socialismo de Estado (PSE). ${ }^{15}$

Toro habló de una democracia funcional o Estado corporativo ${ }^{16}$ y promovió comisiones para analizar el tema de la reforma agraria y de la reforma a la Constitución Política del Estado. ${ }^{17}$ Se lanzó una red de 16 núcleos escolares para la población indígena entre los que se encontraba la famosa Escuela de Warisata. ${ }^{18}$ Se creó también el Ministerio de Minas y petróleo en 1937 y se dio el decreto de confiscación de las propiedades contra la Standard Oil Company (13 de Marzo de 1937).

Enrique Baldivieso (futuro Vice-Presidente de Busch a partir de julio 1937), en una carta a David Toro en marzo de 1937 le escribió que la Revolución de Mayo de 1936 no había sido un "desplazamiento de un partido por otro", una mera rotación de hombres y "menos una revolución" (golpe) como las que se daban en el país. Le recordó que se buscó imponer "la justicia social" y consolidar los derechos del trabajo frente "al dominio incontrolable del capital". Decía que no se trataba de adoptar el socialismo de manera integral pero sí una democracia real en la que la sindicalización constituía uno de sus ejes porque significaba defender los intereses delos trabajadores permitiendo, al mismo tiempo, su participación en el Parlamento. Existieron sin embargo posiciones distintas sobre la sindicalización. Baldivieso era partidario de la sindicalización obligatoria, que se estaba abandonando, y del reconocimiento de la huelga. El se opuso a la sindicalización mixta donde estaban patrones y trabajadores cuando debían existir, de manera separada, sindicatos del trabajo, del capital y de los trabajadores intelectuales. Le recordó también, a David Toro, que se buscaba un Estado intervencionista con inversión en las industrias nacionales, revisión de los impuestos a la minería y nacionalización progresiva de los medios de comunicación y transporte. ${ }^{19}$

13 La sindicalización obligatoria es del 19 de agosto de 1936.

14 La Calle, La Paz, 15 nov. 1936. Cit. Por SCHELCHKOV, “Antes de la Convención”, p. 33. Estuvieron presentes importantes líderes como José Aguirre Gainsborg, Ricardo Anaya, Carlos Montenegro y Fausto Reinaga.

15 SCHELCHKOV. "Antes de la Convención", p. 36 y 40.

16 KLEIN. Orígenes de la revolución nacional boliviana, p. 277 y p. 273-275.

17 KLEIN. Orígenes de la revolución nacional boliviana, p. 286.

18 GOTKOWITZ, Laura. A Revolution for Our Rights: Indigenous Struggles for Land and Justice in Bolivia, 1880-1952. Durham: Duke University Press, 2007 y La revolución antes de la Revolución. Luchas indígenas por tierra y justicia en Bolivia, 1880-1952. Plural: La Paz, 2011, p. 166.

19 Carta de Enrique Baldivieso al Sr. Presidente Coronel David Toro, 2 de mayo de 1937. ABNB PR 153. 
Poco tiempo después, fue Germán Busch quien se hizo cargo del poder (en Julio de 1937) convocando, en noviembre de 1937, a la Convención Nacional. Para entonces, el Sindicato Nacional Ferroviario Independiente, la Legión de Excombatientes y partidos obreros y socialistas crearon el Frente Único Socialista que recibió el apoyo de Busch. Era claro, sin embargo, que el régimen buscó alejarse de las corrientes marxistas, comunistas y anarquistas prohibiendo sus acciones y la difusión de sus ideas así como movimientos considerados de subversión alentadas desde el exterior. ${ }^{20}$

Mientras estas tensiones sucedían en términos políticos, el país continuaba viviendo de la minería. El escritor Sergio Almaraz (fundador del Partido Comunista Boliviano, que luego apoyó al Movimiento Nacionalista Revolucionario), que se caracterizó por su agudeza, escribió que el siglo XX llegó en hombros del estaño. ${ }^{21}$ La producción en Bolivia había duplicado entre 1900 y 1910, de 9.740 TM de fino estaño a 22.885 TM y 47.191 TM en $1929^{22}$ y el porcentaje de la producción boliviana en relación a la producción total de estaño subió de $12 \%$ en 1900, a $20 \%$ en 1910, y a $29 \%$ en 1929. El estaño llegó a representar hasta el $70 \%$ del total del valor de las exportaciones en los años 20. El número de trabajadores empleados se incrementó de 3.000 en 1900 a 17.000 en $1925^{23}$.

Pero el estaño no podía, como sucedió con la plata, basarse en una tecnología local. El proceso de fundición requería hornos que solo podían ser utilizados con energía que no existía en el país o con energía que era extremadamente cara. ${ }^{24}$ Las fundiciones estaban, por tanto, primero en Gran Bretaña y, después de la Primera Guerra Mundial, en los Estados Unidos.

Alrededor de 1929, las principales compañías mineras representaban el $77 \%$ del total de exportaciones ${ }^{25}$ y tres personas fueron los llamados Barones del Estaño: los bolivianos Simón Patiño ${ }^{26}$, Avelino Aramayo, y el alemán judío, Moritz o Mauricio Hotschild. ${ }^{27}$

A pesar de que se ha enfatizado en que la gran minería constituía el Súper Estado, lo cierto es que el Estado boliviano se fue imponiendo paulatinamente. La guerra del Chaco, la depresión y la post-guerra fueron en este sentido cruciales. A partir de entonces, el rol del Estado fue clave porque debía velar por el cumplimiento

20 Decreto Supremo del 27 de marzo de 1938. Se consideraba comunistas, bolcheviques, y extremistas a los que predicaran la abolición de la propiedad privada, de la familia y de los poderes públicos, a los que preconizaran la desaparición de las fronteras o a los que fomentaran la desobediencia (Art. 2). ABNB Orb. 1938-1: 666-668. Schelchkov se refiere a un decreto anti extremista anterior: del 16 de Septiembre de 1936 que ocasionó la salida del país de José Aguirre Gainsborg y José Antonio Arze. SCHELCHKOV. "Antes de la Convención", p. 38.

21 ALMARAZ, Sergio. El Poder y la caída. El estaño en la historia de Bolivia. Cochabam/6ba-La Paz: Los Amigos del Libro, 1967, p. 365.

22 CONTRERAS, Manuel E. The Bolivian Tin Mining Industry in the First Half of the Twentieth Century. University of London. Institute of Latin American Studies. Research Papers 32, 1993, p. 8.

23 CONTRERAS. The Bolivian Tin Mining Industry, p. 2-3.

24 CONTRERAS. The Bolivian Tin Mining Industry, p. 4.

25 Hubo importantes compañías: la de Simón Patiño, la Cia. De Aramayo de Minas de Bolivia, la Cia. De Estaño de Caracoles Guggenheim, la Compañía Minera y Agrícola Oploca de Bolivia, y la Empresa de Estaño Araca. AYUB, Mahmood Ali; HASHIMOTO, Hideo. The Economics of Tin Mining in Bolivia. A World Bank Publication. Washington, D.C., 1985, p. 11.

26 GEDDES, Charles. Patiño: Rey del Estaño. AG Grupo SA: Madrid, 1984, p. 101. En 1927 El New York Times lo identificó como uno de los diez hombres más ricos junto con Rockefeller y con fortunas mayores incluso que Rothschild y Guggenheim. QUEREJAZU, Roberto. Llallagua, historia de una montaña. Editorial Los Amigos del Libro: Cochabamba-La Paz, 1977, p. 145.

27 BIEBER, León. Dr. Moritz (Mauricio) Hochschild: empresario minero, promotor e impulsor de la inmigración judía a Bolivia. Santa Cruz de La Sierra: Editorial El País, 2015; WASZKIS, Helmut. "Moritz Hochschild: $a$ German Jewish Mining Entrepreneur and his Companies in South America, 1911-1965". (Ph.D. Dissertation, Freie Universitaet, Berlin, 2000). 
de la producción de estaño que le correspondía a Bolivia (International Tin Council), distribuyéndola también entre la gran, mediana y pequeña minería.

La distribución de cupos fue ocasión, también, para que los mineros medianos y pequeños se organizaran. En 1932, el gobierno definió que los pequeños mineros eran los que producían menos de 5 toneladas de estaño por mes y menos de 60 al año, ordenando se matricularan en asociaciones departamentales (Arts. 1 y 2 ). Finalmente entre los mineros grandes estaban Patiño, Aramayo y Hochshild. ${ }^{28}$

La distribución de las cuotas de producción entre las empresas y la entrega de divisas crearon también tensiones entre los productores. Se dio así, en 1938, una rivalidad y lucha entre el grupo Patiño y el grupo Hochschild. Este último, buscando tener un mayor porcentaje en el cupo de estaño, afirmó que la producción de las minas del grupo Patiño estaba en declive y que no volvería a tener los niveles de 1929. Echenique, portavoz de Patiño, afirmó que Hochschild quería convencer a la opinión pública que entregaba mayores divisas para el Estado pero que en realidad incluía no solo sus minas de estaño sino también de plata y otras, así como los montos que obtenía de rescates. ${ }^{29}$ En octubre de 1938 se dictó un Decreto Supremo por el cual se redistribuyeron las cuotas mostrando un menor porcentaje de Patiño en beneficio de Hochschild (Cuadro 1) ${ }^{30}$ :

\section{Cuadro 1}

Distribución porcentual de las cuotas de estaño en la minería en Bolivia en 1938

\begin{tabular}{c|c|c}
$\begin{array}{c}\text { Empresas Grandes, Medianas y } \\
\text { Pequeñas }\end{array}$ & Mayo 1938 & Octubre 1938 \\
Grupo Patiño & $50.34 \%$ & $46 \%$ \\
\hline Grupo Hothschild & $18.8 \%$ & $26 \%$ \\
\hline Grupo Aramayo & $5.15 \%$ & $5 \%$ \\
\hline Mineros Medianos & $13.33 \%$ & $13 \%$ \\
\hline Mineros Pequeños & $10.30 \%$ & $10 \%$ \\
\hline
\end{tabular}

Junto a las relaciones muchas veces tensas entre las empresas y el Poder Ejecutivo, los propietarios mineros vivieron la organización de sindicatos y la realización de huelgas y otras medidas de presión de parte de los obreros. El periódico Alas señalaba, por ejemplo, que los sindicatos "surgidos de la noche a la mañana por decreto" se convirtieron "en centros políticos disolventes" en perjuicio del mejoramiento de las condiciones económicas y culturales de sus asociados y que los anarquistas se habían apoderado de ellos. Reprobando las huelgas, afirmaban:

Y si es injusto, insoportable, brutal que el patrono coaccione, violente, aplaste al obrero con la fuerza económica del capital, también lo es que el obrero, con la fuerza del número, coaccione, y aplaste al patrono. ${ }^{31}$

En estos años, el hombre fuerte de la minería en Potosí era precisamente Mauricio Hochschild que había iniciado sus actividades a través de la compra o rescate de minerales..$^{32} Y$ es que el grueso del estaño del cerro rico de Potosí provenía

28 La Calle, La Paz, 13 mayo 1938, p. 5.

29 El Diario, La Paz, 2 oct. 1938, p. 6.

30 La Calle, La Paz, 7 oct. 1938, p. 2.

31 Alas, Potosí, 28 sept. 1938, p. 3.

32 Durante gran parte del siglo XIX, los mineros estaban obligados a vender su mineral al Banco de Rescates 
fundamentalmente de la ingente cantidad de desmontes acumulados durante los cuatro siglos de explotación de la plata. Se trataba, además, de un estaño de baja ley que Hochschild logró que fuera procesado en Alemania en la fundidora Berzelius. Es aparentemente con este tipo de minerales que logró imponerse, poco a poco, comprando a precios más altos que otros mineros rescatadores..$^{33}$ Después de su fase de rescatista pasó a la producción. Un informe de 1929 señalaba que la firma Hochschild logró reunir a distintos propietarios formándose la Compañía Minera Unificada del Cerro de Potosí en base a la Compañía Minera Potosí de los Soux, la de Bebín Hermanos y la Compagnie Aramayo de Mines. La primera puso a disposición, y como socia, las minas y bocaminas que le correspondía, excluyendo los desmontes, además del Ingenio Velarde defundición, concentración y lixiviación, y la Usina eléctrica de Cayara. La firma Bebín hermanos, en cambio, al igual que la Compañía Aramayo, pusieron en administración su empresa, incluyendo los desmontes, aunque al final terminaron vendiéndola a Hochschild. ${ }^{34}$

La Empresa Minera Unificada dobló su producción anual entre 1930 y 1939 alcanzando 3.288 toneladas métricas de estaño fino, basándose en nuevas inversiones, maquinaria y fuentes de agua. ${ }^{35}$ De ahí que en 1938 se consideraba que el 70\% del cerro rico pertenecía a la Unificada y de manera más precisa aún a Hochschild que tenía la parte inferior del cerro considerada la mejor. El gran minero la había solicitado además por hectáreas con el nombre de “La Boliviana" (el resto estaba adjudicado por bocaminas). El restante 30\% estaba dividido entre algunos propietarios, que tenían un $15 \%$ y se pensaba no tardarían en vender su parte. El temor público, esgrimido por algunos grupos y tendencias políticas como las del periódico La Calle, que tenía posiciones socialistas, era que La Unificada se convirtiera en dueña total del cerro y que Potosí se convirtiera en un campamento de la Unificada. ${ }^{36}$ El periódico no perdió oportunidad para deslegitimar su presencia en Potosí. Un artículo se consagró a señalar que a pesar de las declaraciones de Hotshchild de no realizar ningún despido, había destituido a más de 1.600 trabajadores, evitando también su organización. ${ }^{37}$ Frente a esta noticia, Maurizio Hochschild envió una nota aclarando tajantemente que el despido de casi 1.000 obreros era falso y que despidió a 280 trabajadores no mineros (carpinteros, etc.) y ni uno más (esta información consta en los periódicos que consultamos). El periódico La Calle respondió señalando que sus fuentes eran los obreros acreditados en La Paz. ${ }^{38}$

Por entonces, la concepción de que el Estado era finalmente el dueño de las minas $^{39}$ constituía una frase que se esgrimía como una amenaza a las empresas

que compraba a un precio ligeramente menor al mercado. Por la presión que los mineros propietarios ejercieron, lograron obtener la libertad de venta. En 1902 se recordaba esta libertad con la condición de pagar el impuesto de exportación en la Aduana (Ley de 13 de diciembre de 1902). Lexivox.org.

33 TENORIO, Carlos. "Orígenes de las firmas del industrial minero. Mauricio Hochschild Hirsch en Bolivia: crecimiento económico en Potosí (1921-1939)”. (Tesis de Licenciatura de Historia, UMSA, 2011), p. 48.

34 TENORIO. "Orígenes de las firmas del industrial minero", p. 138-142 y ss. Años más tarde, la Cía. Hochschild recordaba que esa unión se había hecho a fin de evitar los continuos enfrentamientos por el sistema de bocaminas para incorporarse al sistema de hectáreas, base de la formación del catastro minero. (p. 145).

35 CONTRERAS. The Bolivian Tin Mining Industry, p. 16.

36 La Calle, La Paz, 11 jun. 1938. Este periódico fue inicialmente órgano del Partido Socialista y tuvo entre sus articulistas y colaboradores a intelectuales importantes como Carlos Montenegro, Augusto Céspedes, Armando Arce, José Cuadros Quiroga y Nazario Pardo Valle.

37 Primero destituyó a 100, luego a 300 y finalmente a 500. Se afirmó también, que después de haber comprado Meeting, se hizo cargo de 14 bocaminas y prometió no despedir, pero lo hizo; que lo mismo sucedió con las minas de Duncan, Fox, Hayland y Bebein hermanos, donde exoneró a más de 900 trabajadores. Se dijo así que la Unificada se deshizo de 1.600 trabajadores. La Calle, La Paz, 16-06-1938.

38 La Calle, La Paz, 18 jun. 1938, p. 5.

39 La Calle, La Paz, 21 mar. 1937. 
recordándoles que sus minas podrían ser "socializadas". ${ }^{40}$ Esta visión legitimaba el derecho del Estado a tener parte de las utilidades de las minas ${ }^{41}$ El periódico La Calle abanderó estas posiciones estatistas. Uno de sus artículos titulaba "Los mineros contra el Estado". En él se afirmaba que, aunque se suponía que los industriales mineros debían en principio ser los más interesados en producir, no lo hacían aludiendo que entregaban sus divisas a un precio que no correspondía a la realidad $^{42}$ a pesar de que el gobierno les había ofrecido muchas facilidades. Ante esta situación decían que podía darse "uno de los más importantes postulados del socialismo como es la reversión de las minas al Estado". ${ }^{43}$ Hochschild respondió afirmando que "La ruina de la minería" no era "la de los mineros sino la del país todo" precisando que Bolivia tenía los más altos costos de producción; pocos trabajadores y que habían alrededor de 25.000 a 30.000 obreros que ganaban más de 4 chelines al días y tenían facilidades de habitación, escuelas, hospitales libres y pulperías baratas en las grandes minas mientras que la gran parte, por lo menos el $90 \%,{ }^{44}$ no tenía esa situación. El empresario se quejó también del sentimiento que se había creado en contra de la gan minería. ${ }^{45}$ Es en este contexto que tiene lugar la Convención Nacional de 1938.

\section{La Convención de 1938}

La Convención de 1938 fue una de las respuestas frente a la crisis que desencadenó la Guerra del Chaco así como una de sus concreciones. Ella expresó los deseos de cambio y la necesidad de un rencauzamiento de su destino político. Fue crucial porque en ella se dio mayor importancia y rol al Estado y porque las discusiones que se generaron - a pesar de que no siempre se concretizaron en cambios constitucionales y políticos inmediatos - dieron los lineamientos, el ambiente y las rutas en las que Bolivia se embarcaría los próximos cincuenta años: allí estuvieron las semillas de la revolución de 1952, sus futuros líderes, la presencia y voz de los obreros que por primera vez ingresaban al parlamento; la discusión "sobre los indígenas" y "sobre las mujeres" y por tanto su propia "ausencia"; la importancia de las voces orientales y la creación del noveno departamento de Bolivia. La Convención marcó, también, y sin lugar a dudas, ciertos quiebres: representantes de tendencias denominadas "socialistas" y tal vez de manera más precisa no liberales, representantes de obreros, representantes de los jóvenes, representantes de diferentes sectores económicos urbanos, representantes de Santa Cruz y Beni estuvieron presentes. De ahí que Abecia señalara que "La convención del 38 era una especie de insurgencia popular por su ansia de abolir las formas concretas de explotación del país por la rosca minero-feudal". ${ }^{46}$

Los registros cívicos se abrieron en agosto de 1937 para elegir, en marzo de 1938, a los representantes a la Convención. La convocatoria permitió la participación de los partidos políticos pero también de dos organizaciones fundamentales en la

40 Alas, Potosí, 11 oct. 1938.

41 La Calle, La Paz, 21 mar. 1937.

42 La Calle, La Paz, 19 mar. 1937, p. 3.

43 La Calle, La Paz, 18 mar. 1937. El POR (Partido Obrero Revolucionario), conocido también como Bloque Socialista de Izquierda y que dio su apoyo a David Toro, ya había propuesto la nacionalización de las minas, latifundios, bancos, etc. SCHELCHKOV. “Antes de la Convención”, p. 10.

44 Alas, Potosí, 14 dic. 1937, p. 3.

45 Alas, Potosí, 14 feb. 1937, p. 3.

46 BALDIVIESO, Valentín Abecia. Historia del Parlamento, T. III. Bolivia: Congreso Nacional, 1997, p. 32 
época como la Confederación Sindical de Trabajadores de Bolivia y la Legión de Ex-Combatientes. ${ }^{47}$ La confederación buscaba conformar el Partido Socialista en el país. ${ }^{48}$ Para Gotkowitz, el programa de la Confederación Socialista Boliviana que había sido creada en 1935 con integrantes del Partido Nacionalista de Siles, miembros del grupo Beta Gama ${ }^{49}$ de Hernán Siles Suazo, con Enrique Baldivieso de la Célula Socialista y Carlos Montenegro y que fue rebautizada como Partido Socialista ${ }^{50}$ - fue clave porque sentó la base para los temas de discusión en la Convención. En Enero de 1936 se había realizado además el Primer Congreso Regional de la Izquierda dando lugar al Frente Único Socialista compuesto por la Confederación Sindical de Trabajadores de Bolivia (CSTB), los ex combatientes de la LEC, los sindicatos ferroviarios, el Frente Popular de Potosí, parte del Partido Socialista de Estado, la fracción de los republicanos, encabezada por Gabriel Gosálvez, el Partido Obrero y el flamante Partido Socialista Independiente (PSI) en el que militaban Paz Estenssoro y Montenegro. A la cabeza del FUS estaba Armando Campero Arce..$^{51}$ El Frente había propuesto la sindicalización general y la reforma política necesaria para crear un Estado de Sindicatos, la Socialización de la Industria, la Reforma Agraria con la colectivización de las tierras y otras medidas revolucionarias. ${ }^{22}$ Precisemos también que la CSTB había recibido el apoyo de David Toro y propiciaba el ejercicio de una democracia funcional progresista, la nacionalización de las minas, petróleos, ferrocarriles y bancos, y la destrucción de los latifundios. ${ }^{53}$

En las primeras semanas de la Asamblea hubo alrededor de 101 convencionales entre diputados y senadores, participando, por primera vez, sectores populares y obreros. Uno de los oradores más destacados en la Convención, Augusto Céspedes, afirmó, sin embargo, que no estaba presente la "mayoría del país" y aunque reconoció que esto sucedía en todas partes del mundo, advirtió que era una de las primeras veces en que llegaron a ocupar sitios dentro del propio Estado $^{54}$ y dentro de la Convención. De hecho, los partícipes de la Convención

47 KLEIN. Orígenes de la revolución nacional boliviana, 309. Fue esta Legión la que había aprobado un plan funcional y corporativo de organización para la Convención de acuerdo a la siguiente organización y representación: 4 diputados de los mineros; 3 diputados de los interesescomerciales; 3 diputados de los profesionales; 4 diputados de los universitários; 3 diputados de los profesores; 2 diputados de los periodistas; 3 diputados del ejército; 5 diputados de la legión de Ex - Combatientes; 5 diputados del movimiento laboral; 3 diputados para los intereses agrícolas y de los hacendados; 3 diputados para la clase indígena; 3 para los grupos feministas; 4 diputados para la Industria desglosados de la siguiente manera; 2 para la Asociación de Mineros; 2 para las pequeñas asociaciones mineras (KLEIN. Orígenes de la revolución nacional boliviana, p. 311)

48 Informe sobre la situación boliviana, 1936. Documento. En Stefanoni y Schelchkov: 326-327.

49 Según Schelchkov, Beta Gama se fundó en 1935 con partidarios del aprismo, exestudiantes de izquierda y marxistas como J. Suazo Cuenca, L. Iturralde Chinel, Víctor Andrade, Walter Guevara Arze y Hernán Siles Suazo (estos dos últimos fueron los los ideólogos del nacionalismo revolucionario) que se llamó también Acción Socialista Beta Gama. "Antes de la Convención”, p. 1-2.

50 En marzo de 1936 con antiguos activistas del partido nacionalista Enrique Baldivieso, Carlos Montenegro, José Tamayo y Moisés Alvarez. SCHELCHKOV. "Antes de la Convención”, p. 3.

51 STEFANONI, Pablo. "Los inconformistas del Centenario Intelectuales, socialismo y nación en una Bolivia en crisis (1925-1939)". (Tesis de Doctorado, Facultad de Filosofía y Letras, Universidad de Buenos Aires 2014). El libro es del 2015, Editorial Plural, p. 336.

52 SCHELCHKOV. "Antes de la Convención”, p. 3.

53 Documento: Informe sobre la situación boliviana, 1936. En STEFANONI, Pablo; SCHELCHKOV, Andrey (Coords.). Historia de las izquierdas bolivianas. Archivos y documentos (1920-1940). CIS: La Paz, 2016, p. 326-327. La CSTB se afilió después a la Confederación de Trabajadores de América Latina (CTAL) de extrema izquierda bajo la dirección de Vicente Lombardo Toledo. KLEIN. Orígenes de la revolución nacional boliviana, p. 290.

54 Aquí no está representada la masa indígena; en ninguna parte del mundo están representadas, en los parlamentos, las grandes masas populares, así sean trabajadoras y aún de la clase media, con la circunstancia de que ésta es la primera oportunidad en que los trabajadores han llegado a ocupar una 
fueron atacados por el Diario quien calificó al evento como un "taller de sastres y peluqueros... ignorantes y atrasados". 55

En Potosí se conformó el Frente Popular cuya actuación fue importante involucrando a la Confederación de Ferroviarios, Tranviarios y Ramas Anexas, Confederación de Trabajadores de Bolivia, Partido Obrero y Federación Obrera del Trabajo. ${ }^{56}$ A nombre del Frente Popular estuvieron Alfredo Arratia, Carlos Medinaceli y Fernando Siñani. ${ }^{57}$ Pablo Careaga, denominado también "Camarada", fue otro representante de los obreros, cuya incorporación a la Asamblea no fue nada fácil..$^{8}$ Otros representantes, del Bloque Obrero Parlamentario, fueron Waldo Alvarez y Carlos Cortez. ${ }^{59}$

El Partido Socialista Revolucionario (PSR) estuvo también presente con Soriano que se identificó como fundador del Partido que "gestó la revolución... y no usufructuó del poder". Se declaró también opuesto al socialismo de los dirigentes obreros y de los ExCombatientes de Bolivia. ${ }^{60}$ Otros miembros o por lo menos simpatizantes de este partido fueron Lucio Lanza Solares y Oscar E. Araúz ya que recibieron el apoyo del PSR frente a un ataque que recibieron de la Federación Obrera Socialista de Potosí. ${ }^{61}$

La inauguración de la Convención estuvo marcada por discursos de esperanza renovadora. Se habló del pueblo constituido en Estado ${ }^{62}$, de la participación de los que no participaban, de la presencia del socialismo y la ausencia de los partidos tradicionales, del Frente Popular de Potosí que hablaba a nombre del pueblo y del proletariado, del fin de un ciclo político histórico del liberalismo, del advenimiento de un nuevo sistema político y de una nueva conciencia colectiva. ${ }^{63}$

situación dentro del Estado... Redactor de la Convención de 1938, T. I.: 175.

55 El sacerdote y representante por La Paz Chávez Lobatón escribió: “Hasta hace poco se pensó que sólo los capitalistas y los doctores eran los únicos que podían ser los mejores defensores de la democracia. Por ese prejuicio les extraña ahora que hayan ingresado al Parlamento dos sacerdotes y varios obreros, denominando despectivamente a este recinto taller de sastres y peluqueros y hasta se dice que la Convención es una reunión de ignorantes y atrasados. Al presente se ha dado participación al obrerismo en el manejo de la cosa pública, al indígena se le ha reconocido sus derechos como componente de la nacionalidad, y tiene el orgullo de levantar la cabeza contra sus explotadores. Nosotros tenemos el derecho de decir muy alto que así humildes, así ignorantes, estamos contribuyendo al progreso de la patria levantando a las clases oprimidas. Con esto vamos demostrando que desaparecerá la creencia de que sólo los doctores y los aristócratas eran los únicos capacitados para venir al Parlamento. Hoy se ha roto la tradición de que los obreros e indígenas deben servir de instrumento a los privilegiados" (BALDIVIESO. Historia del Parlamento, T. II, p. 227).

56 Redactor de la Convención de 1938, T. I, p. 73. Medinaceli había estudiado Derecho pero fue sobre todo un escritor y crítico literario. Es muy conocido por ser fundador del grupo Gesta Bárbara creada en 1918 y por su obra La Chaskañawi publicada en 1947. Arratia era marxista y fue candidato para Diputado por la ciudad de Potosí por el Frente Único Socialista (FUS). Nota del FUS al Presidente Busch, La Paz 12 de febrero de 1938, 6 p. El FUS comprendía varias agrupaciones. ABNB PR 190.

57 Redactor de la Convención de 1938, Tomo 1, p. 31.

58 Redactor de la Convención de 1938, T. I: 105.

59 BALDIVIESO. Historia del Parlamento, 1999 T. III, p. 29. Estuvieron también José Antonio Camacho, Tomás Chávez Lovatón, Renato Riverín, Adolfo Román, Antonio Murguía, Lucio Vargas. (p. 37).

60 Redactor de la Convención de 1938, T.I, p. 148.

61 Otros convencionales ligados al PSR fueron García Agreda, Julio Pantoja Estensoro, Taborga, Burgoa, Mogro Moreno, Bilbao Rioja, Vargas Soto, Saldaña, Eguino Zaballa, Rodríguez Quiroga, Jordán Cuellar, Arana Urioste, Reyes Barrón, Marquel Abel, Montellano Gambarte, que firmaron una iniciativa liderada por el PRS (Redactor de la Convención de 1938, T. I, p. 534-535).

62 H. Céspedes. Ver Redactor de la Convención de 1938, T. I, p. 56.

63 El Vice-Presidente de la República señaló que era la "primera vez que en el Parlamento de Bolivia se presenta un selecto bloque de representantes auténticos de la clase trabajadora" (Redactor, 1938, T. I: 85). Villarroel Claure señaló, por ejemplo, que la diferencia con la Asamblea de 1880 era que en la anterior predominaba el liberalismo y en ésta el socialismo, afirmando que no era una "doctrina exótica" sino la situación del obrero boliviano (Redactor, T. I, p.130. Ver también: p. 133). “Esta es una Convención Nacional de composición socialista sin intervención de los partidos tradicionales, los mismos que en las horas trágicas de la guerra negaron su concurso a los combatientes" (Redactor, T. I, p. 50). Ver igualmente las 
La perspectiva de un cambio económico social era fundamental. Se consideraba que habían conquistas económico-colectivas surgidas de la Guerra del Chaco que implicaban "la nueva conciencia colectiva: política económica dirigida; política dirigida de reivindicaciones sociales; política efectiva de emancipación del indio para liberarlo de su irredentismo". ${ }^{64}$ Riverin, el Presidente de la Convención Nacional dijo que la aplicación del liberalismo económico tuvo como consecuencia que Bolivia permaneciera como país productor de materias primas comprando productos manufacturados; y que con la explotación que hacía no obtenía ventaja alguna. ${ }^{65}$

Había además un diagnóstico compartido sobre el país y Eguino Zaballa, simpatizante del PRS (Partido Republicano Socialista), lo sintetizó en uno de sus discursos. Para él, la guerra demostró la debilidad de la estructura estatal, la poca cohesión social, la mediterraneidad del país, la poca articulación entre sus partes, la escasa población y la despoblación en grandes extensiones del territorio, la existencia, finalmente, de gran parte de la población "no incorporada a la nacionalidad". ${ }^{66}$ Otro convencional señaló que el Estado era en Bolivia un "organismo débil, convertido en mero administrador en una especie de gendarme de ese imperialismo" y que su presupuesto, de apenas 200.000.000 Bs. no alcanzaba ni para sus necesidades. ${ }^{67}$

La respuesta, a la situación también compartida, más allá de las posiciones políticas, fue fortalecer el Estado: el Estado como la entidad máxima y no el individuo, el Estado regulador de la economía, la educación, el trabajo, la incorporación del indio, la familia, la convivencia internacional, la política religiosa, el régimen agrario, la previsión social, el régimen municipal, las universidades". Un Estado no sólo policía o administrador, sino un Estado regulador por excelencia y propulsor de toda la economía y el progreso ${ }^{68}$. Un Estado social, finalmente. Así, en lugar de pensar un Estado como la fuerza que se oponía al derecho individual, limitando su ejercicio, ahora se pensaba en términos del interés del organismo social y, citando a León Dugit ${ }^{69}$ se consideró que el Estado era un grupo de individuos puestos al servicio de las sociedad para ciertos fines. Se enfatizó también en que se estaba frente al fin de los principios democrático-liberales y al fin de los principios de la Revolución Francesa. ${ }^{70}$

Para Villarroel Claure, el liberalismo que propugnaba la libertad individual era una libertad con servidumbre porque "la nueva revolución" no era ya de "la

presentaciones que hicieron sus representantes: Medinaceli, Arratia, Siñani del frente Popular (Redactor, T. I, p. 31). Sobre el nuevo sistema político: Discurso del Presidente de la Convención Renato Riverín, (Redactor, T. I, p. 36). Sobre la conciencia colectiva, ver el discurso del Ministro de Gobierno (Redactor, T. I., p. 3).

El Frente Popular representaba, se decía, a las fuerzas de "izquierda” de Potosí. Telegrama, 22 de marzo de 1937. En: ABNB PR 130. Se buscó también organizar Frentes Populares en otras ciudades. En una carta desde Oruro, el abogado intelectual Josermo Murillo Bacarreza decía que ingresarían al Frente todos los sindicatos organizados, incluso los de médicos, abogados, ingenieros. Carta de Murillo Bacarreza a David Toro, Oruro 29 de marzo de 1937. ABNB PR 154.

64 Redactor de la Convención de 1938, T. I, p. 643.

65 La Calle, La Paz, 12 ago. 1938.

66 Redactor de la Convención de 1938, T. II, p. 311.

67 Redactor de la Convención de 1938, T. II, p. 396 y 321.

68 Redactor de la Convención de 1938, T. II, p. 312.

69 Jurista francés y autor de una serie de libros como "El estado, el derecho y la ley positiva". Criticó la noción individualista heredada de los juristas romanos, de los escolásticos medievales y de la revolución francesa. Desde superspectiva esa construcción debía ser superada porque era incapaz de articular la relación entre los individuos y las colectividades. Influenciado por Durkheim, planteó que la ley debía estar basada en la solidaridad social y para él, incluso la propiedad debía cumplir una función.

H. Montellano, ver Redactor de la Convención de 1938, T. II, p. 345. 
liberación social sino de la liberación económica". ${ }^{71}$ En este sentido, refiriéndose al profesor Adler de la Universidad de Viena ${ }^{72}$, señaló que, en la democracia funcional, la voluntad nacional está expresada teniendo en cuenta la opinión de las organizaciones, de los grupos y sobre todo de los obreros y empleados. ${ }^{73} \mathrm{La}$ democracia fue considerada, entonces, como la de los derechos económicos del obrero y del indio, y sin duda más del primero que del segundo. Así, el obrero era "como el mineral originario del que han de extraerse las sustancias más refinadas y útiles de la sociedad. El obrero conserva nuestras virtudes y nuestros vicios; forma la sustancia esencial de nuestra sociedad" y no sólo era el obrero manual sino también el intelectual porque el proletariado boliviano lo forman también el empleado, el pequeño comerciante y el intelectual. ${ }^{74}$

Los temas debatidos por la Convención de 1938 resultaron fundantes de la política boliviana a partir de entonces, y era también, como lo señaló Céspedes, un “organismo político viviente" que se constituía en una tribuna para la propagación de ideas políticas y sociales 75 esbozando también las tendencias del propio proceso de 1952.

\section{Los k'ajchas en el cerro Rico de Potosí y las discusiones en 1938 alrededor del proyecto en su favor}

Desde 1917, el Poder Ejecutivo determinó que ciertos recursos pudieran ser considerados como reserva fiscal subrayando, con ello, el "dominio originario" del Estado sobre ellos y las adjudicaciones que podía o no hacer. ${ }^{76}$ En 1929 , después de la crisis, se decretó como reserva fiscal al cerro Rico de Potosí (se supone que en los lugares que no tenían adjudicación) y, el año 1932, por la caída del estaño, "enormes masas de trabajadores fueron echados a la calle." 77 Aparentemente estas razones llevaron al Estado a arrendar las bocaminas abandonadas, a los desocupados, sin que se tuvieran, los resultados esperados. ${ }^{78}$ De ahí que esta medida se canceló los primeros meses de $1937 .{ }^{79}$ El periódico La Calle se opuso tajantemente a tal decisión señalando que el "pueblo potosino" esperaba que sus representantes evitaran la posibilidad de ceder sus riquezas "por un plato de lentejas". ${ }^{80}$ El Ministro explicó a la prensa que se había pensado dar trabajo a 2.000 desocupados pero que solo arrendaron 20 minas, quedando 180 sin interesados

71 Redactor de la Convención de 1938, T. II, p. 427.

72 Se trata del Socialista Austríaco Víctor Adler, del grupo conocido como "los austro marxistas" que desarrollaron el tema del desarrollo de las "naciones sin historia".

73 Redactor de la Convención de 1938, T. II, p. 428.

74 Redactor de la Convención de 1938, T. II, p. 428.

75 Redactor de la Convención de 1938, T. I, p. 175.

76 La Ley del 5 de diciembre de 1917 autorizaba al Poder Ejecutivo a declarar reserva fiscal. Art. 1. El Ejecutivo podrá decretar toda vez que creyere conveniente, la reserva fiscal de tierras o regiones en que se hallasen sustancias o productos pertenecientes al Estado, resguardando derechos adquiridos. En consecuencia, no se efectuarán concesiones respecto de los bienes reservados. / y el 28 de Julio de 1920 se declaró reserva fiscal en toda la provincia Frías y por tanto el propio Cerro Rico de Potosí (Redactor de la Convención de 1938, T.I: 266).

77 Redactor de la Convención de 1938, T. I., p. 318-319.

78 TENORIO. "Orígenes de las firmas del industrial minero Mauricio Hochschild Hirsch", p. 152.

79 La Calle, La Paz, 14 may. 1937, p. 6. En otro artículo se informó que por Decreto Ley de 19 de marzo se estableció la cancelación de contratos de alquiler de bocaminas en Potosí y su reversión al estado.

80 La Calle, La Paz, 11 may. 1937, p. 5. 
razón por la que se continuó con la reserva fiscal. ${ }^{81} \mathrm{La}$ Calle anunció entonces que "2.000 k'ajchas de Potosí serían privados de las minas que explotaban", es decir que 2.000 obreros kajchas contratados en las pequeñas empresas, "esto es mineros chicos", se quedarían sin nada siendo obligados a trabajar en la Unificada con sueldos de hambre que fluctuaban entre Bs. 1.50 y Bs. $3 .{ }^{82}$ Vale la pena resaltar aquí esa ambigüedad en torno su situación: fueron calificados de mineros chicos pero también de obreros de las pequeñas empresas.

¿Pero quiénes y cómo eran vistos los k’ajchas en esta época? En 1937, las autoridades de la Oficina del Ministerio de Trabajo describieron a los k'ajchas de Potosí de manera muy certera. Por un lado, los definieron como obreros ya que trabajaban en las obras mineras y empresas que beneficiaban de una y otra forma a los "patrones". Pero los diferenciaban también de los clásicos obreros por cuanto trabajaban de manera independiente, sin recibir un salario fijo, corriendo los riesgos de la pérdida y la ganancia. No eran claramente jornaleros por día, no eran contratistas y tampoco subcontratistas, aunque había algunos casos. Se parecían mucho más, se decía, a los obreros a destajo. ${ }^{83}$ Nos parece fundamental subrayar el hecho de que no eran concesionarios/propietarios de las minas.

La situación podía presentar algunas mayores especificidades que mostraba la variación que existía entre ellos. Habían k'ajchas que trabajaban solos; otros asociados entre dos personas o más, habiendo incluso los que empleaban "bajo su dependencia" otros obreros. En este último caso se introducía el nombre de contratista. Era el caso de Renato Barrón que tenía 17 obreros a quienes pagaba distintos jornales siendo el más alto de Bs. 7.50 por día y el más bajo 2.60 Bs. y el promedio de Bs. 3. Esta persona fue calificada, sin embargo, como contratista, sin capital propio, que obtenía anticipos en dinero o en herramientas recibiendo Bs. 1 el kilo cuando los minerales tenían ley del 40\%; Bs. 0,70 cuando la ley era del 30\% y Bs. 0,50 cuando la ley era del $20 \%{ }^{84}$ En otras minas de la provincia, los k'ajchas trabajaban también por cuenta y riesgo propios, con sus herramientas, pero bajo la vigilancia de mayordomos. Todo el mineral explotado lo vendían al propietario como a un simple rescatador. En este caso estamos claramente ante un obrero a destajo. ${ }^{85}$ Esta situación explica que cuando se discutía el Código del Trabajo se señalara que a los k’ajchas podía considerárselos como trabajadores a destajo (o destajistas) pero también como contratistas. ${ }^{86}$

En la Convención de 1938, uno de los temas que se discutió fue precisamente el proyecto presentado por el Frente Popular para la explotación del cerro de

81 La Calle, La Paz, 19 mar. 1937. En la Convención se recordó también que la suspensión de los arrendamientos dejó a los k'ajchas con deudas frente a las casas que les habían facilitado fondos para su trabajo. Redactor de la Convención de 1938, T. I., p. 267.

82 La Calle, La Paz, 18 mar. 1937.

83 “El ckaccha es también un obrero ya que trabaja materialmente en obras o empresas ... beneficiando de una u otra manera al patrón pero se diferencia [del] primero: en que trabajan independientemente el tiempo que quieren y creen conveniente y segundo: en que su trabajo lo realiza sin capital, corriendo los riesgos de la pérdida y la ganancia; tercero no están sometidos a vigilancia alguna del dueño de la industria quien cuida únicamente los robos que pudieran cometer; y cuarto: que estos no pueden exijir el salario mínimo... ya que ellos llevan el control del tiempo que trabajan y ellos deben soportar las perdidas, en caso de tenerlas"..

"Por lo expuesto los ckacchas no son jornaleros; tampoco son contratistas o subcontratistas y menos empresarios y se asemejan por las condiciones en que ejecutan su labor a los obreros a destajo, pero por el hecho de no encontrarse sujetos a ninguna reglamentación, horario y vigilancia, constituyen una clase especial de obreros a quienes habría que comprenderlos de una manera típica". Por tanto, dice que las leyes sociales no se refieren a los obreros ckachas. Potosí, 30 de junio de 1937 (Alas, Potosí, 4 jul. 1937, p. 2).

84 Alas, Potosí, 4 jul. 1937, p. 2.

85 Potosí, 30 de junio de 1937, Alas, 4 jul. 1937, p. 2.

86 Comentarios al Código de Trabajo, ver Alas, Potosí 18 oct. 1938. 
Potosí. Para entonces se recordaba la situación de la minería y de Potosí en estos términos:

\begin{abstract}
... habiendo sido el Departamento de Potosí el más rico, nos ofrece ahora el espectáculo de una pobreza franciscana y que Bolivia, teniendo la base económica del estaño sea ahora el país que está al borde de la quiebra, todo esto ha obedecido a la circunstancia de que el Estado no se preocupó de cuidar sus reservas y recursos naturales de producción. ${ }^{87}$
\end{abstract}

La discusión que desencadenó el proyecto y que tomó varias sesiones es fascinante por varias razones: si bien era simple porque planteaba dar las bocaminas abandonadas a los k'ajchas, era un proyecto que hoy denominaríamos alternativo en tanto era una respuesta concreta frente a su situación, frente a la de los mineros medianos y grande y frente al Estado. Es interesante también porque alrededor de él se condensaron las perspectivas de la época y más allá de las posiciones políticas se encontraba un mismo patrón extractivista sobre lo que hoy denominaríamos desarrollo económico; interesante también porque es posible discernir fuertes tensiones entre las lecturas teóricas de la época enfrentadas a la realidad concreta del país. Interesante, finalmente, porque las prioridades se dibujaron claramente, prioridades en nombre de múltiples y variados argumentos que no favorecieron siempre a los K'ajchas. En otras palabras, encontramos también un cierto conservadurismo en estos convencionales progresistas y en muchos de ellos un desdén e incluso un desprecio.

El Convencional Arratia, del Bloque Parlamentario obrero, fue uno de sus grandes impulsores y defensores. Señaló que habían más de 1.600 obreros desocupados que podían vivir si se levantaba esa reserva. Recordó que la Federación Central de Trabajadores de Potosí había hecho esa demanda y aunque no se había tomado tal decisión, se permitió que la Prefectura arrendara bocaminas a los desocupados, lo que constituía indudablemente un importante antecedente local. Recordó también, que muchos trabajadores k'ajchas "que así se llaman los mineros que trabajan en minas que no son de su propiedad con la obligación de dar un $25 \%$ o $50 \%$ de producción a los dueños de minas, tomaron en arrendamiento las bocaminas y de esta manera hicieron frente a la miseria que los acosaba en esos instantes". 88

El proyecto presentado a la Convención iba a permitir que los k’ajchas arrendaran las bocaminas del Estado durante 50 años. Como su producción se calculó en 7 toneladas al mes y en 84 al año, se estipuló que el Estado podría recibir más de 500.000 Bs., cifra superior - se decía - a la que Hochschild había ofrecido para adjudicarse las bocaminas del cerro. ${ }^{89}$ El proyecto favorecería adicionalmente a unas 800 personas que con sus familiares alcanzaban al $40 \%$ de la población potosina ${ }^{90}$ en un momento de gran desocupación. ${ }^{91}$ Finalmente era también una

87 H. Araúz, Redactor de la Convención de 1938, T. I., p. 316.

88 Redactor de la Convención de 1938, T.I., p. 267.

89 Si el precio era de 170 libras se tendrían 14.280 libras y si la libra esterlina equivalía a Bs. 120 siguiendo el cambio oficial se tendrían 1.713.600; si el cambio bajaba a 160 se deberían tener 2.284 .800 de lo que el Estado percibe el 25\% o sea Bs. 571.200 (Arratia, Redactor de la Convención de 1938, T. I., p. 268).

90 Velasco, T. I., p. 271. Pero el Ministro se refiere a 1.600 mineros kacchas que serían son los "desechados" por razones de salud [enfermos] y que no quieren asumir la responsabilidad que les correspondería (Redactor de la Convención de 1938, T. I., p. 327).

91 "El sacrificio que pudiéramos hacer con los trabajadores de Potosí que alcanzan a 5.000 sería insignificante, 
medida que se la tomaba en nombre de la defensa de la Nación: ${ }^{92}$

Cuando nosotros, en el artículo $1^{\circ}$. del proyecto declaramos y pedimos que el Estado determine su dominio directo quiere decir que defendemos los derechos de la Nación, que velamos sus intereses, que deseamos poner a salvo al país de las pretensiones del capitalismo, evitar que estas últimas reservas caigan en sus manos, en fin poner atajo al dominio de empresas imperialistas... ${ }^{93}$

El proyecto causó muchas inquietudes. Los argumentos más leves iban a cuestionar si entregar las bocaminas a "una célula socialista de obreros" tendría efectos negativos para la economía o si generaría ingresos más o menos equivalentes a los de las empresas. ${ }^{94}$ Otros se preguntaron si las concesiones de bocaminas para la explotación de minerales podían ser "científicas" en su explotación, si esa explotación encarecía o abarataba el producto y si el orden público no sería perturbado. ${ }^{95}$

Uno de los opositores más duros fue otro representante de Potosí, Lanza Solares, que adujo que el proyecto era "una alucinación socialista o un espejismo absurdo". ${ }^{96}$ Señaló que el arrendamiento de bocaminas estuvo vigente por más de 5 años presentándose 40 mineros a solicitar pertenencias abandonadas pero que apenas con veinte se logró realizar contratos, lo que demostraba que no era fácil explotar las mencionadas bocaminas ya sea por dificultades en la extracción de minerales o porque ya no había realmente ningún producto explotable. Sostuvo, también, que por el arrendamiento apenas se tuvo la insignificante suma de Bs. 3.320 y que, en algunos años, como en 1934, no se obtuvo nada. Finalmente, que el proyecto era inconstitucional porque desde el momento en que se concedía el arrendamiento a los k'ajchas constituidos o por constituir en sindicato y no a otros mineros, se estaría implantando un monopolio en oposición al Art. 4 de la Constitución. ${ }^{97}$

Una carta enviada a Mauricio Hochschild de A. Bonifaz, que aparentemente trabajaba en la Empresa, sintetiza también la visión que se tenía. Dijo que "los elementos de izquierda disfrazados de socialistas quieren... ponerse en contacto con los obreros de la Unificada" para explotar las minas de la Compañía. Añadió que ése era el significado de entregar las bocaminas abandonadas del Cerro Rico de Potosí, pretensión a la que debería oponerse como atentatorio contra sus derechos. Afirmaba también que era absolutamente falso que hubieran desocupados en la ciudad, que se pagaban buenos jornales con una pulpería barata; que si existían minas abandonadas era porque no había qué explotar y que, para ponerlas en funcionamiento, tendrían que invertir por lo menos unos 5.000 Bs. En estas circunstancias consideraba que menos aún podrían ponerlas en funcionamiento obreros retirados y enfermos como decía el Gobierno; finalmente, que la Unificada no permitiría que, bajo título de haber recibido las bocaminas abandonadas, los k’ajchas, en consorcio con los obreros de la Unificada, explotarían sus minerales.

comparado con los males que acarrearía para la sociedad la desocupación de éstos porque el Estado no podría darles trabajo y tendría que soportar una carga más" (H. Ayala Cuéllar. Redactor de la Convención de 1938 T.I: 549).

92 Redactor de la Convención de 1938, T.I., p. 267.

93 Arratia, Redactor de la Convención de 1938, T.I., p. 268

94 Ayala Gamboa, Redactor de la Convención de 1938, T. I., p. 318.

95 Romero Loza, Redactor de la Convención de 1938, T.I. p. 317.

96 Lanza Solares, Redactor de la Convención de 1938, T.I: 537.

97 Lanza Solares, Redactor de la Convención de 1938, T. I, p. 537-38. 
Señalaba también que esto podía suceder porque el Gobierno escuchaba más al Frente Popular y a los sindicatos que a las Empresas Mineras. Decía que lo mejor sería, finalmente, que se suspendiera la Reserva Fiscal y que de las 600 minas abandonadas, la mitad debía ser solicitada por la Compañía y que cada una no valía ni $2.000 \mathrm{Bs} .{ }^{8}$

Los que defendían el proyecto de los k'ajchas señalaban que el peligro radicaba en que la empresa Hochschild rematara las bocaminas sobre la base de 500.000 y que el Estado transfiriera sus derechos a la Unificada. El H. Ossio precisó que la Unificada había ido reduciendo la parte que laboreaban los kajchas y que ese monto había sido ofrecido por el empresario cuando esas bocaminas, en manos de los kacchas, darían más de Bs. 1.800 .000 anuales. ${ }^{99}$

La presión de los interesados estuvo también presente. Los trabajadores Aurelio Alcoba, Saturnino Guzmán y Ricardo Ramírez, enviados de la Confederación Sindical Obrera de Potosí llegaron a La Paz para gestionar la entrega de las 200 bocaminas al Sindicato de Metalurgistas. La noticia, en el periódico La Calle, enfatizaba que estaban luchando para que Potosí no se convirtiera en un feudo. ${ }^{100}$

Los Ministros de Minas, Dionisio Foianni, y de Comercio e Industria, Vicente Leytón, estaban decididos en apoyar a los k'ajchas. Los argumentos esgrimidos son interesantes. El primero expresó que era "un deber de asistencia social" y que sería una injusticia privarlos de "una posibilidad económica". El segundo explicó la Reserva Fiscal y las acusaciones que tuvieron. Señaló que declarar reserva fiscal al cerro no era una política marxista recordando que fueron las leyes de 1900 y 1920, en gobiernos liberales, las que declararon reservas fiscales al subsuelo. ${ }^{101}$ Dijo también, que por lo menos desde la ley de 1917, el Ejecutivo quiso "conservar para el Estado los yacimientos Ilámense petrolíferos y otros minerales" y que tal determinación, firmada por el Ex Presidente Tejada Sorzano, bajo la presidencia de José Gutiérrez Guerra, significaba que "empezaba el Estado a apreciar la necesidad de socializar la gran industria, consolidando la riqueza en provecho propio". Sin embargo, se decía que esa política se la calificaba ahora de marxista. ${ }^{102}$ Informaron, también, que la Unificada daba trabajo a unas 800 personas que obtenían 60 toneladas al mes mientras que se calculaba que 1.800 personas (k'ajchas) podían producir 7 toneladas al mes y 84 al año lo que significarían 16.000 libras esterlinas obteniendo el Estado mayores ingresos que los que lograrían si remataban esas concesiones. Puntualizó que la economía pública tenía por objetivo defender la vida del pueblo y así, aunque el Estado perdiera, estaría obligado a atender las necesidades de esos obreros. Para él "la riqueza de Potosí no estaba supeditada a beneficios personales sino a necesidades sociales" y que las fuentes de producción debían ser controladas por el Estado. ${ }^{103}$

Pero hay tres argumentos que nos interesa particularmente analizar: el planteamiento de que el sistema de los k’ajchas constituía un sistema primitivo, pobre y no industrial; que eran pequeños propietarios, y que era un proyecto "localista" debiéndose plantear, por tanto, verdaderas medidas socialistas.

98 ABNB PR 182 Carta a Mauricio Hochschild de A. Bonifaz, Potosí, 20 de junio de 1938.

99 La Calle, La Paz, 8 jun. 1938, p. 4.

100 La Calle, La Paz, 15 jun. 1938.

101 Recordó que la ley de 1880 en su art. 3 decía que el subsuelo pertenece al Estado. Ministro Leytón, Redactor de la Convención de 1938, T. I., p. 320.

102 Redactor de la Convención de 1938, T.I, p. 320-321.

103 La Calle, La Paz, 14 jun. 1938, p. 5. 
Entregar la explotación de las bocaminas del cerro de Potosí al sindicato de los K'ajchas fue considerado inaceptable porque significaba volver al "sistema primitivo" y colonial:

... la iniciativa no ha de remediar en nada a esos hombres desgastados, tuberculosos, incapacitados para el trabajo; ya lo ha demostrado la experiencia, que no corresponde a determinado gobierno de la República sino a la época colonial. Se dice que el paria minero no está en igualdad de condiciones con los empresarios o grandes capitalistas ni con los rescatadores; entonces hay que buscar esa igualdad por medio de medidas atinadas, sólo así encontraremos la verdadera manera de proteger a los pequeños trabajadores. ${ }^{104}$

En lugar del sistema primitivo y colonial se encontraban los sueños con una producción "científica" industrial, tecnificada y en grande. ${ }^{105}$

... debe tenerse en cuenta que el sentido de la economía moderna tiende a la concentración de la producción mediante métodos o sistemas técnicos perfeccionados para alcanzar el máximo de rendimiento en las industrias. Entregando al sindicato de Cachas minas que apenas tienen el 1 y $1 / 2 \%$ equivaldría volver a los tiempos coloniales mantener una producción pobre y anular una posible fuente de ingreso...

El criterio y plan del Estado debe ser industrializar las bocaminas, modernizar los sistemas de producción para que esos minerales de escasa ley den índices elevados que beneficien al Estado y también al Sindicato de Kacchas (Romero Loza, T. I, p. 325).

Otro convencional informó que las bocaminas "con títulos perfeccionados y registrados en el Padrón de Minas son 368, de ellas 211 pertenecen a la Cía. Unificada y el resto a los particulares". Estimaba que las bocaminas abandonadas eran alrededor de 1.800 en el pasado pero que hoy no debían existir más de 800 . De acuerdo a su criterio esas minas debían ser empresas organizadas con una explotación científica de los minerales de baja ley y que entregar a los "Cachas" que todavía no tienen los capitales para su explotación era un problema. ${ }^{106}$

En contraposición a la modernización e industrialización, los k’ajchas eran considerados mineros aún más pobres que los peones: mientras éstos ganaban entre 8 y 10 Bs., los k'ajchas percibían apenas la suma de Bs. 2.40 de jornal diario. Si no tenían dinero, no tenían ni instrumentos, ni capitales, careciendo, entonces, del "espíritu de organización industrial en grande" sin poder dar ningún beneficio al Estado y menos a ellos mismos. En estas circunstancias, los k'ajchas, contando "sólo con su voluntad" nunca podrían constituirse en una empresa seria con capitales e instrumentos modernos de trabajo porque el estaño era muy pobre y requería de "buenas plantas de beneficio" para su recuperación. Se afirmaba, categóricamente, que el costo de producción sólo podía bajar con la inversión de fuertes capitales como los de la Cía. Minera Unificada del Cerro de Potosí. ${ }^{107} \mathrm{El}$ sueño industrial estaba presente:

104 Redactor de la Convención de 1938, T.I: 367.

105 "Está bien que se busque el beneficio colectivo pero desde le punto de vista de la explotación tecnificada en grande y no en pequeño" (H. Romero Loza, Redactor de la Convención de 1938, T.I, p. 325).

106 Redactor de la Convención de 1938, T.I, p. 545-46.

107 Lanza Solares, Redactor de la Convención de 1938, T.I, p. 538. 
El período de la rutina que imperó durante el coloniaje en trabajos de minas ha pasado. Hoy, sólo a base de grandes plantas de beneficio de minerales se puede levantar la industria principal del país, dando así beneficios a la clase asalariada y al país todo. Los mineros que trabajan sólo con el barreno y el pico, jamás pueden competir con las grandes empresas, las que siempre por sus métodos modernos de trabajo estarán por encima de éstos hasta que tarde o temprano tendrán que sucumbir o subordinarse... Esta es la verdad señores convencionales. ${ }^{108}$

Pero otra perspectiva radicalmente distinta era la de verlos no como obreros mineros asalariados sino como coproductores de las pertenencias mineras. En otras palabras, como personas que trabajaban en sociedad con los dueños de las pertenencias mineras; una especie de pequeños patrones porque no tenían ni días fijos de trabajo ni horario alguno y porque bajo su dependencia se encontraban otros peones, barreteros, carreros, etc., sin reconocerles ninguna ley social a favor de esos trabajadores. El verdadero "pobre" fue presentado, entonces, por el propietario de la mina que tiene que cumplir con sus obligaciones con el Estado proporcionándoles además pulpería, herramientas y habilitos para que cada semana o cada 15 días reciban una tercera parte de la producción en bruto dejando que el saldo se venda a otros compradores o a él mismo a precio del mercado local. Pero al mismo tiempo que consideraban que los kajchas no eran obreros proletarios, sostenían que ninguna casa rescatadora les concedería préstamos, que ellos habían estado ya de deudores de la casa Duncan, Fox y Cía. y que el Banco minero sólo concedía préstamos a mineros solventes! ${ }^{109}$

Ver a los k'ajchas como obreros negándoles al mismo tiempo su condición proletaria era enfrentarse verdaderamente a la "esencia" de Bolivia de ayer y de hoy: un país con muy pequeñas industrias y por tanto con escasos verdaderos proletarios y con una mayoría de dueños de sus medios de producción (comunarios e incluso k'ajchas) y sin embargo "obreros" por su pobreza, aunque no encajaban en las lecciones aprendidas del socialismo, en la literatura de la época y en la realidad de otros países. Y sin embargo, la particularidad que había sido captada no recibía la suficiente atención. El propio Arratia se encontró atrapado entre sus lecturas y la realidad, y en lugar de reivindicar su originalidad, y pensar en alternativas en función de esas particularidades, contra argumentaba tratando de convencerse y convencer que si se les cedía las bocaminas se transformarían en todo lo que esperaban e imaginaban los socialistas de la época: serían obreros "organizados" y con horarios, tendrían estatutos y dejarían los vestigios de "patrones" que tenían, ${ }^{110}$ característica que se esgrimió para negar y deslegitimar la importancia del proyecto porque no estaba destinado a "verdaderos obreros y proletarios".

Para muchos otros, el programa presentado era más bien una iniciativa "localista" opuesta a un verdadero programa eficaz y socialista que no encaraba realmente “el problema económico” 111 del país. Arratia defendió el proyecto respondiendo a los diversos argumentos. Adujo, en primer lugar, que el proyecto, sustentado por gran número de trabajadores contemplaba dos aspectos:

\footnotetext{
108 Redactor de la Convención de 1938, T.I, p. 538. García Agreda señaló que no se podía obligar al Ejecutivo a explotar las bocaminas abandonadas mediante contratos de arrendamiento con el sindicato Kacchas y que deberían entregarse las abandonadas a una persona jurídica con responsabilidad y compromiso! (Redactor de la Convención de 1938, T. I., p. 570-71).

109 Lanza Solares, Redactor de la Convención de 1938, T.I: 539 y 540.

110 Redactor de la Convención de 1938, T. I: 543

111 H. Montellano, Redactor de la Convención de 1938, T.I: 365 y 367.
} 
el uno antiimperialista, cuando declara el dominio directo y perpetuo de las bocaminas abandonadas en el Cerro de Potosí, substrayéndolas en esa forma a la apropiación del capital financiero, vale decir, del capital de empresas extranjeras; y el otro, socialista, mirado desde dos ángulos de observación: el primero porque trata de implantar el trabajo colectivo de los miembros de un sindicato en la explotación de minerales para el aprovechamiento también colectivo de las utilidades, con la participación respectiva a favor del Estado; el segundo se refiere a que, por no haber los gobiernos anteriores, denominados tradicionales, en su tiempo y oportunidad conservado y explotado las fuentes de riqueza nacional, en beneficio y provecho de la colectividad, esos deberes, en el momento presente, han sido históricamente transferidos para su realización a las fuerzas de la izquierda. ${ }^{112}$

El proyecto se veía, al mismo tiempo, casi como una misión: la de "salvar las riquezas nacionales de manos de empresas imperialistas". Era indudablemente una manera de poner fin a la situación en la que el propio país se encontraba, es decir retomar las riquezas en sus manos porque "la nación" que no era "dueña de sus riquezas no puede tener libertad política y económica ya que todas las libertades descansan precisamente en la riqueza de un pueblo" y que por ello teníamos un país semisoberano que no puede hacer nada sin consultar a Londres o Nueva York. ${ }^{113}$

Muchos de los otros argumentos que tuvo que rebatir eran muy concretos y mucho más fuertes incluso que los más abstractos. Arratia planteó, en este sentido, que no entendía que se cuestionara el tiempo de arrendamiento que les darían a los k'ajchas cuando se habían realizado concesiones mineras a "empresas imperialistas" por más de 90 años con participación hipotética de un $11 \%,{ }^{114}$ y los ferrocarriles, a la Railway, sin que el país se inmutara. Finalmente, que no entendía por qué no se podía confiar en las posibilidades de tecnificación e industrialización de la explotación en manos de los k'ajchas ya que la propia Compañía Unificada recurría y mantenía en sus minas a más de 1.000 k’ajchas que trabajaban en forma rudimentaria". ${ }^{115}$

El proyecto se encaminó a su análisis en la comisión respectiva y el que se fue aprobando ${ }^{116}$ no correspondía al original. ${ }^{17}$ Sin embargo, el proyecto de Ley planteaba que al finalizar el catastro del cerro Rico, las bocaminas abandonadas fuesen a explotarse directamente por el Estado o mediante arrendamiento a los trabajadores k'ajchas con un sistema controlado por el Estado o por el Banco Minero. ${ }^{118}$ Esta ley significaba que se abrió la posibilidad para que los k'ajchas

112 Redactor de la Convención de 1938, T.I, p. 541.

113 Arratia, Redactor de la Convención de 1938 T.I, p. 542.

114 Arratia, Redactor de la Convención de 1938, T.I, p. 268

115 Redactor de la Convención de 1938, T.I, p. 543-544.

116 Redactor de la Convención de 1938, T.I, p. 551 y 552.

117 Al parecer hubo en un momento tres proyectos: el original presentado por el H. Ossio Ruíz, el sustitutivo de H. Arratia y el de la Comisión de Minería. Se sostuvo que Ossio Ruíz y Arratia retiraron sus proyectos de motu propio. Luego, Landívar Zambrana, secretario, leyó el informe de la Comisión de Minería proponiendo un proyecto sustitutivo al original relativo al arrendamiento de bocaminas del Cerro Rico (Redactor de la Convención de 1938, T.I: 536). Se consideró en grande el proyecto y se informó, en la Convención, de que la ley a las bocaminas fue vetada por el Ejecutivo. Redactor de la Convención de 1938, T. II: 17.

118 ABNB PR 207. Ministerio de Minas. Proyecto de Ley, Convención Nacional. La Paz, Julio de 1938. El Informe de la Comisión de Minería al Proyecto De Ley No. 25 decía que después de vistos los proyectos presentados por Luis Ossio Ruiz, Clavijo y el sustitutivo presentado por H. Arratia llegaron a las siguientes conclusiones: 1. Que ambos proyectos tienden a conservar el dominio directo y perpetuo de las boca minas abandonadas ( $y$ del terreno franco en la zona minera propiedad del Estado) en el Cerro Rico de Potosí, evitando sean transferidas o cedidas a título gratuito u oneroso y que el Estado debe conservar el dominio directo; 2. Que no se haga adjudicación a Empresas o personas particulares y que no hay 
fueran reconocidos como actores fundamentales de la minería, cambiando su situación de obreros a destajo. Después de 1938, la organización de los k’ajchas en sindicatos constituyó, así, una etapa previa a su transformación en cooperativas mineras las que aparecieron recién entre 1939 y $1944^{119}$ como se puede apreciar en el Cuadro 2.

\section{Cuadro 2}

\section{Formación de Sindicatos y Cooperativas en el Cerro de Potosí, 1936-1970}

\begin{tabular}{|c|c|c|c|c|c|}
\hline $\begin{array}{l}\text { Nombre del } \\
\text { Sindicato }\end{array}$ & $\begin{array}{c}\text { Fecha de Creación } \\
\text { Mención }\end{array}$ & $\begin{array}{l}\text { Minas o } \\
\text { empresas }\end{array}$ & $\begin{array}{l}\text { Fuente } \\
\text { primaria }\end{array}$ & $\begin{array}{c}\text { Referencia Libro } \\
\text { Absie }\end{array}$ & $\begin{array}{l}\text { Personas } \\
\text { integrantes }\end{array}$ \\
\hline $\begin{array}{l}\text { Sindicato Central } \\
\text { de Metalúrgicos }\end{array}$ & 1936 & CMUCP & $\begin{array}{c}\text { Alas, 2-10- } \\
1936\end{array}$ & p. 232 & \\
\hline $\begin{array}{c}\text { Sindicato de } \\
\text { Mineros del Cerro } \\
\text { de Potosí }\end{array}$ & 1936 & & & $\begin{array}{l}\text { "organizado } \\
\text { de acuerdo } \\
\text { a la sociedad } \\
\text { cooperativa } \\
\text { de mineros } \\
\text { ckacchas" }\end{array}$ & $\begin{array}{c}\text { Doroteo Moreno y } \\
\text { Antonio Rollano }\end{array}$ \\
\hline $\begin{array}{c}\text { Sindicato de } \\
\text { Ckacchas de la } \\
\text { Unificada se une } \\
\text { con el Sindicato de } \\
\text { Metalúrgicos }\end{array}$ & $\begin{array}{c}1941 \text { y } 1943 \\
\text { (refundación) } \\
\text { Estatutos de } 1944\end{array}$ & CMUCP & & p. 233 & $\begin{array}{c}\text { Sabas Elías. Pedro } \\
\text { Arismendi } \\
\text { Antonio Rlllano y } \\
\text { Gregorio Huallpa }\end{array}$ \\
\hline $\begin{array}{l}\text { Sindicato Kacchas } \\
\text { Libres y Pallirsi }\end{array}$ & $\begin{array}{c}1949 \\
{[1939]^{1}}\end{array}$ & CMUCP & $\begin{array}{c}\text { Alas, 17-8- } \\
1949\end{array}$ & p.233 & $\begin{array}{c}\text { Uno de los } \\
\text { fundadores: Sabas } \\
\text { Elías. Doroteo } \\
\text { Moreno Pedro } \\
\text { Arismendi } \\
\text { Tenía } 300 \text { el } \\
\text { momento de su } \\
\text { fundación }\end{array}$ \\
\hline $\begin{array}{c}\text { Sindicato de } \\
\text { Ckacchas sección } \\
\text { veneros de la CMP }\end{array}$ & 1946 & $\begin{array}{c}\text { Vendían a } \\
\text { Ingenio Thuru } \\
\text { de Luis Soux }\end{array}$ & & p. 238 & \\
\hline $\begin{array}{l}\text { Sindicato de } \\
\text { Ckacchas, } \\
\text { Jornaleros de } \\
\text { minas chicas e } \\
\text { independientes } \\
\text { Se transforma } \\
\text { en Cooperativa } \\
\text { Minera Central } \\
\text { Mixta de Minas } \\
\text { Libres Lda. }\end{array}$ & $\begin{array}{l}1946 \\
1953\end{array}$ & & & p. 239 & \\
\hline $\begin{array}{l}\text { Cooperativa } \\
\text { Reserva Fiscal }\end{array}$ & 1951 & & & p. 240 & $\begin{array}{l}\text { Arrendatarios } \\
\text { Recibieron } \\
\text { en concesión } \\
\text { del BANMIN } \\
\text { bocaminas }\end{array}$ \\
\hline
\end{tabular}

inconveniente para que el Estado ensaye su explotación mediante sociedad o arrendamiento; 3. Que no es posible señalar un sindicato como beneficiario o constreñir al Banco Minero a ser fomentador de este sindicato (ABNB PR 207:27-28). Proyecto de ley para evitar monopolios: Art 1. Que concluida la catastración del cerro, el terreno franco y las bocaminas se den en arrendamiento a un sindicato de mineros kcacchas que mayores ventajas ofrezcan al Estado; Art. 2. Que el estado queda facultado para otorgarlas por el plazo máximo de 10 años (ABNB PR 207. Ministerio de Minas. Proyecto de Ley, Convención Nacional. La Paz, Julio de 1938.? 28); Art. 4. Derogadas las leyes contrarias Firman E. Sejas, L. Ossio Riz, E. Fajardo. A. Arratia, S. Suárez.

27 de junio 1938. Aparece también otra fecha: 18 de junio de 1939.

119 Las Cooperativas se organizaron en la Federación Departamental de Cooperativas Mineras que pasó a ser conocida como Consejo Central de Cooperativas el 1ero. De mayo de 1955. ALURRALDE ANAYA, Antonio. Cooperativas Mineras en Bolivia. La Paz: Don Bosco, 1973. 


\begin{tabular}{c|c|c|c|c|c}
$\begin{array}{c}\text { Nombre del } \\
\text { Sindicato }\end{array}$ & $\begin{array}{c}\text { Fecha de Creación } \\
\text { Mención }\end{array}$ & $\begin{array}{c}\text { Minas o } \\
\text { empresas }\end{array}$ & $\begin{array}{c}\text { Fuente } \\
\text { primaria }\end{array}$ & $\begin{array}{c}\text { Referencia Libro } \\
\text { Absie }\end{array}$ & $\begin{array}{c}\text { Personas } \\
\text { integrantes }\end{array}$ \\
$\begin{array}{c}\text { Sindicato de } \\
\text { Veneros de la } \\
\text { COMIBOL }\end{array}$ & 1953 & Sección Thuru & & p. 238 & $\begin{array}{c}\text { Se volvieron } \\
\text { arrendatarios: } \\
\text { cancelaban a } \\
\text { la COMIBOL } \\
\text { un alquiler del } \\
20 \% \text { además } \\
\text { de regalías; }\end{array}$ \\
$\begin{array}{c}\text { Transformado } \\
\text { en Sindicato de } \\
\text { Veneros de la } \\
\text { COMIBOL }\end{array}$ & $1953 \%$ \\
\hline $\begin{array}{c}\text { Sindicato de la } \\
\text { Mina Encarnación }\end{array}$ & 1970 & pespectivamente \\
\hline $\begin{array}{c}\text { Cooperativa } \\
\text { Minera de Potosí } \\
\text { (COMPOTOSI) }\end{array}$ & & p. 238-239 & $\begin{array}{c}\text { En base al } \\
\text { Sindicato de } \\
\text { Ckacchas sección } \\
\text { Veneros }\end{array}$ \\
\hline
\end{tabular}

\section{Conclusiones}

Como hemos visto, en los años posteriores a la Guerra del Chaco se dieron profundas reflexiones sobre la situación del país empezándose a plantear acciones antes inimaginadas. El diagnóstico podía variar y también las perspectivas que se esbozaban a futuro. Sin embargo, fue en este período que se fue dotando de contenido a lo que se llamó en la época la justicia social, en contra del individualismo liberal. Se pensó también en los nuevos roles que debía asumir el Estado. Fue en los hechos un cambio de rumbo que buscó darle mayor protagonismo político y económico para tener un Estado más fuerte y para la sociedad. Como parte fundamental de esta perspectiva se fue planteando la "socialización de las minas" y se fue gestando el proyecto de su nacionalización. En términos políticos, es importante mencionar que se fue deslegitimando, paulatinamente, a los grandes empresarios, es decir a los barones del estaño y a su "rosca". El caso de Hochschild y Potosí resulta paradigmático. El escritor Augusto Céspedes habló en la Convención de Bolivia como nación colonial bajo dominación imperialista. ${ }^{20}$ Pero más importante aún, es que uno de los trabajos que marcaría profundamente el análisis político de todos los grupos de centro izquierda e izquierda hasta hoy, se gestó entonces publicándose en 1943. Nos referimos al libro de Carlos Montenegro, titulado Nacionalismo y Coloniaje que planteó la historia de Bolivia como una lucha entre la nación y la anti-nación. La primera representaba los intereses foráneos mientras que la segunda representaba el bloque en que las clases populares eran dominantes. Los enemigos estuvieron encarnados en las grandes empresas mineras que fueron "extranjerizadas", incluyendo al "cholo" Patiño. Pero en lugar de esos barones no emergieron directamente los trabajadores y/o los pequeños empresarios o la minería chica, sino más bien el Estado como dueño y productor que podía dirigir la industria y sus asalariados. El Estado afirmó su dominio sobre sus recursos y como tal podía decidir explotarlos directa o indirectamente. A partir de la Convención de 1938, se abrió la posibilidad, por primera vez desde mediados del siglo XVIII, de que los k'ajchas pudieran arrendar o recibir en concesión las propiedades estatales y esto fue lo que sucedió, aunque de manera efectiva algunas décadas después. La Cooperativa Unificada

120 KLEIN. Orígenes de la revolución nacional boliviana, p. 324. 
Potosí, que se había formado en 1944, trabajó después de la Revolución de 1952 en pertenencias obtenidas por peticiones directas en 300 parajes que pertenecían a los 300 socios (en las secciones San Sergio, San Germán y San Carlos) y en otras minas arrendadas a COMIBOL (Corporación Minera Boliviana, en Santa Rita, Rosario Bajo y Candelaria Bajo). ${ }^{121}$ Y la situación se fue multiplicando a través de los años. Es indudable que el Estado adquirió más poder. Sin embargo, en la larga duración, las empresas extranjeras y transnacionales han vuelto. En muchos casos, como en el famoso cerro de Potosí, se fue desarrollando un modus vivendi entre el Estado representado en la $\mathrm{COMIBOL}$, las corporaciones mineras transnacionales y los cooperativistas (Cuadro 3). Así, en pleno período del MAS y de Evo Morales, COMIBOL arrienda las minas a las cooperativas que explotan los minerales y los venden por toneladas a las transnacionales como la Empresa Manquiri y el Proyecto San Bartolomé establecido el 2008 y que hoy es una subsidiaria de la Coeur d'Alene Mines Corporation, una de las mayores empresas de plata del mundo. Esta empresa presenta gráficamente ese modus vivendi que implica que los cooperativistas se han convertido en los proveedores, en la base de la cadena de producción sin que la empresa tenga ningún costo de mano de obra.

\section{Cuadro 3 \\ El modus vivendi entre las empresas, la COMIBOL o empresa del Estado y las Cooperativas}

\section{Coeur}

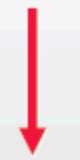

Empresa Minera Manquiri, S.A.

(Wholly owned subsidiary of Coeur)

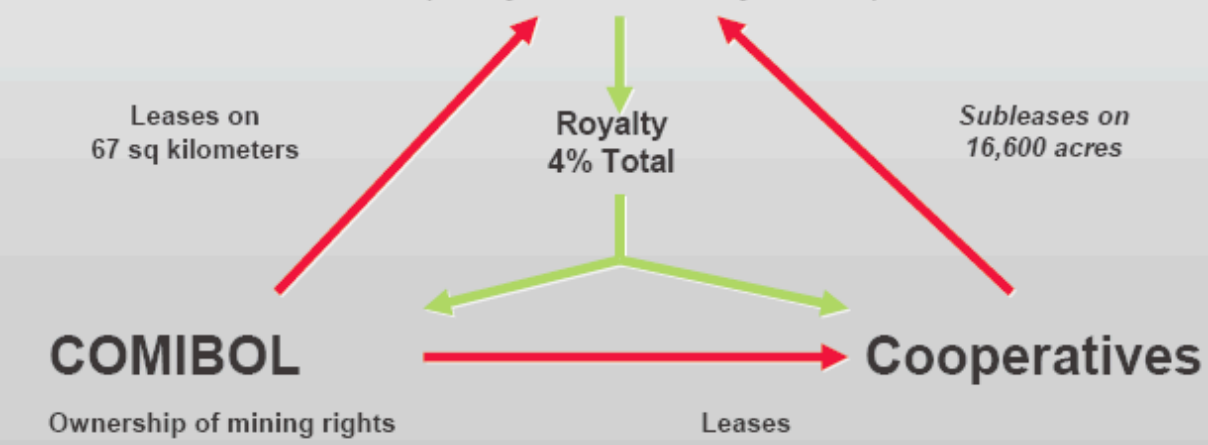

Fuente: Coeur Mining, San Bartolomé update and Overview. Coeur. The precious metal company.

El mundo de los cooperativistas se ha desarrollado entonces, en los hechos, en la lógica de las pequeñas empresas dando lugar a desigualdades muy grandes en su seno. Paradójicamente, desde el estado se piensa que los cooperativistas no pueden ser pequeños empresarios porque desde fines de los 50 hasta hoy, se sostiene que el lucro no debe ser la base de su asociación. El mundo de los cooperativistas

121 ALURRALDE ANAYA. Cooperativas Mineras en Bolivia, p. 284. En 1979, por otra parte, se señalaba que el $85 \%$ de las cooperativas arrendaban parajes del Estado por solo cinco años, pagando el $4.5 \%$ sobre la producción bruta y el resto, es decir el 15\% tenía concesiones. Rogelio Villegas Velásquez, Las Cooperativas en Bolivia, 1979. 
parece haberse desarrollado encubriendo sus acciones y actividades del estado. Sin capital y sin tecnología adecuada, las cooperativas constituyen la base de las cadenas internacionales de producción dando lugar también a relaciones de explotación y a grandes desigualdades en su seno. Los cooperativistas de hoy no son los k'ajchas del siglo XVIII o de 1930 o 1940. Lograron de alguna manera ser considerados como arrendatarios y concesionarios, pero hoy el tema no es sólo de propiedad sino de tecnología.

Recebido em 06/11/2017

Aprovado em 23/04/2018 